\title{
Study of Shallow Low-Enthalpy Geothermal Resources Using Integrated Geophysical Methods
}

\author{
Lara De GIORGI and Giovanni LEUCCI \\ IBAM - National Council of Research, Lecce, Italy \\ e-mail: g.leucci@ibam.cnr.it
}

\begin{abstract}
The paper is focused on low enthalpy geothermal exploration performed in south Italy and provides an integrated presentation of geological, hydrogeological, and geophysical surveys carried out in the area of municipality of Lecce. Geological and hydrogeological models were performed using the stratigraphical data from 51 wells. A ground-water flow (direction and velocity) model was obtained. Using the same wells data, the ground-water annual temperature was modeled. Furthermore, the ground surface temperature records from ten meteorological stations were studied. This allowed us to obtain a model related to the variations of the temperature at different depths in the subsoil. Integrated geophysical surveys were carried out in order to explore the low-enthalpy geothermal fluids and to evaluate the results of the model. Electrical resistivity tomography (ERT) and self-potential (SP) methods were used.

The results obtained upon integrating the geophysical data with the models show a low-enthalpy geothermal resource constituted by a shallow ground-water system.
\end{abstract}

Key words: low enthalpy, 3D geological and hydrogeological models, $3 \mathrm{D}$ high resolution geophysics.

Ownership: Institute of Geophysics, Polish Academy of Sciences;

(C) 2015 De Giorgi and Leucci. This is an open access article distributed under the Creative Commons Attribution-NonCommercial-NoDerivs license,

http://creativecommons.org/licenses/by-nc-nd/3.0/. 


\section{INTRODUCTION}

One of the key components crucial in economic and social development is energy. Most energy sources at some stage are dependent on ecosystem services (Williamson and McCormick 2008). How these forms of energy are harnessed and employed makes the energy use a critical environmental issue, as its sourcing, production, transmission, and consumption often impact the ecosystems. Ecosystems are also keys to help in meeting the growing energy demand. Thus, to increase future energy supplies in a sustainable way, ecosystems need to be well-managed.

The current energy exploration has resulted in environmental changes with significant local, regional and global effects. Biodiversity loss and global warming threats continue to place an increasing demand for environmentally sound energy systems. Presently, the shift is toward clean renewable energy sources among which geothermal energy is the most attractive because of its relatively benign nature (de Jesus 1997).

The term "geothermal energy" is understood not only as the heat contained within the Earth. Geothermal energy is more often used to "indicate that part of the Earth's heat that can, or could be recovered and exploited by man" (Dickson and Fanelli 2004). In general, geothermal energy is extracted from geothermal reservoirs. According to the Encyclopedia of Physical Science and Technology (Meyers 1992), geothermal reservoirs are defined as a "geometrically definable volume of permeable rock which contains a proven reserve of thermal energy, such as water or steam that can be extracted in a practical, economic way". In other words, a geothermal reservoir could be considered a geothermal system consisting of three main elements: a heat source, a reservoir, and a fluid, which is the carrier that transfers the heat (Dickson and Fanelli 2004). This heat has two primary origins: (i) the decay of natural radioactive isotopes, and (ii) the original heat from gravitational energy released during the earth's formation. This heat is continuously streaming towards the surface by conduction, radiation and advection via mass transport. On average, the temperature in the continental crust increases with depth by $30^{\circ} \mathrm{K} / \mathrm{km}$, reaching high temperatures in the earth's interior ( $\sim 900^{\circ} \mathrm{C}$ at the crust-mantle boundary).

Such high-enthalpy resources (Lee 2001) can be used for electricity generation, and their availability is restricted to regions with high heat flow. On the other sides, when geothermal energy is characterized by low temperature (low-enthalpy resources), it is often tapped using specialized technology. According to the temperature range, the low-enthalpy resources can be utilized for direct heating of dwellings (e.g., using aquifer systems) (e.g., Muffler and Cataldi 1978, Hochstein 1990, Benderitter and Cormy 1990, Haenel et al. 1988). Cooler resources $\left(<30^{\circ} \mathrm{C}\right.$ for compression heat pumps, $<50{ }^{\circ} \mathrm{C}$ 
for absorption heat pumps) are made accessible through the use of the socalled geothermal heat pump systems.

In the context of possible use of low-enthalpy geothermal resources, the aim of this paper is to investigate the groundwater flow system that characterizes the Municipality of Lecce (Apulia Region, southern Italy), in order to verify its potentiality as source of geothermal low enthalpy energy for its application in heating and cooling systems to be used in private buildings.

\subsection{Low-enthalpy geothermal resources}

The main advantage of geothermal energy at low or intermediate temperature range is related to its direct use, because this resource is more widespread and exists at economic drilling depths (Lund 2007). In addition, parts of a geothermal system could be used, for example, as an underground thermal energy storage system (Andersson 2007). The general strategy of geothermal resource development starts with the development of a conceptual model of the potential geothermal resource.

The review of existing data, especially on geology (structural geology, stress field, hydraulic transport properties, thermal rock properties, petrography, and mineralogy), temperature, heat flow, and geochemistry form the basis to identify the potential geothermal reservoir and to estimate its size and its heat content. Low enthalpy geothermal energy, however, can be obtained at any place with the help of a ground-source heat pump from the soil, rocks, and from groundwater. It has a high potential for heating and cooling of buildings, especially in temperate and polar zones. However, an optimization of low-enthalpy exploitation requires general knowledge on the heat flow and groundwater flow properties of the aquifer. In addition, new exploration data should be integrated into site-specific geological models, useful for geothermal wells location and path planning, the risk assessment concerning the borehole stability, and the simulation of the reservoir behavior (during production). Models and computer simulations to predict the reservoir behavior are important tools useful for a sustainable, reliable, and efficient energy provision, for the planning of further reservoir treatments, and for the consideration of environmental aspects related to the exploitation of geothermal energy. The drilling of new wells, which provide additional information on the local conditions and, thus, implement the model, should be carried out according to the need of geothermal wells and the site-specific conditions. The last step in the development of the geothermal resource requires the installation and management of the whole geothermal system.

\subsection{Geothermal energy and ecosystem services}

Geothermal energy is defined as a carbon-free form of energy. However, the use of geothermal resources in a particular location can affect the availability 
of groundwater resource and the land-use due to urban sprawl. There is the recognition that the overexploitation of natural resources has gravely affected many ecosystem services (MEA 2005). Ecosystem services are defined as the benefits that ecosystems provide to people (Costanza et al. 1997). They have been classified in: (i) provisioning ecosystem services (the provision of food, water, etc.), (ii) regulating ecosystem services (i.e., erosion control), (iii) supporting ecosystem services (i.e., soil formation), and (iv) cultural ecosystem services (recreation and life fulfillment) (MEA 2005). Several ecosystem services have a direct linkage with groundwater storage, even if this interdependency is little considered in decision-making processes. Groundwater system can provide important regulating services, such as water regulation, water purification and, indirectly, erosion regulation, flood control, and climate regulation (Bergkamp and Cross 2006). In terms of water regulation, groundwater plays an important role in the hydrological cycle and it is strongly connected with surface water resources (Falkenmark and Rockström 2004, Morris et al. 2003, Shaw 1994) by sustaining the stream flow during dry periods (Ward and Robinson 1990). For what concerns water purification, groundwater hosts a biological component that purifies water from organic compounds and potential human pathogens (Herman et al. 2001). The indirect regulating services are related, for instance, to the regulation of soil erosion, by providing water to vegetation cover (Malanson 1993), and to the buffering of climate variability (FAO 2003). In addition, groundwater can be seen in terms of supporting ecosystem services because it provides the basis for the hydrological cycle (Ward and Robinson 1990) and water is essential for living organisms.

At the same time, ecosystems, like wetlands, forests, and some kinds of land-covers, provide services that are crucial to maintain groundwater systems. Changes in land-cover, for instance, can affect the volume of recharge into groundwater aquifers. Thus, several management approaches are now becoming available to address groundwater depletion and deterioration, mainly based on new technologies and participatory approaches.

\section{STUDY AREA}

The study area is the Municipality of Lecce in the Salento peninsula (Apulia region, southern Italy) (Fig. 1). Apulia region is the emerged part of a plate stretching between the Ionian Sea and the Adriatic Sea, which constitutes the foreland of both Apenninic and Dinaric orogens. It comprises a Variscan basement covered by a 3-5 km thick Mesozoic carbonate sequence (the Calcari delle Murge unit), and overlain by thin deposits of Paleogene (Bosellini et al. 1999, Bossio et al. 1992, 1998, 1999, Margiotta 1999, Margiotta and Ricchetti 2002), Neogene (Bossio et al. 1992, 1994, 1998), and Quater- 

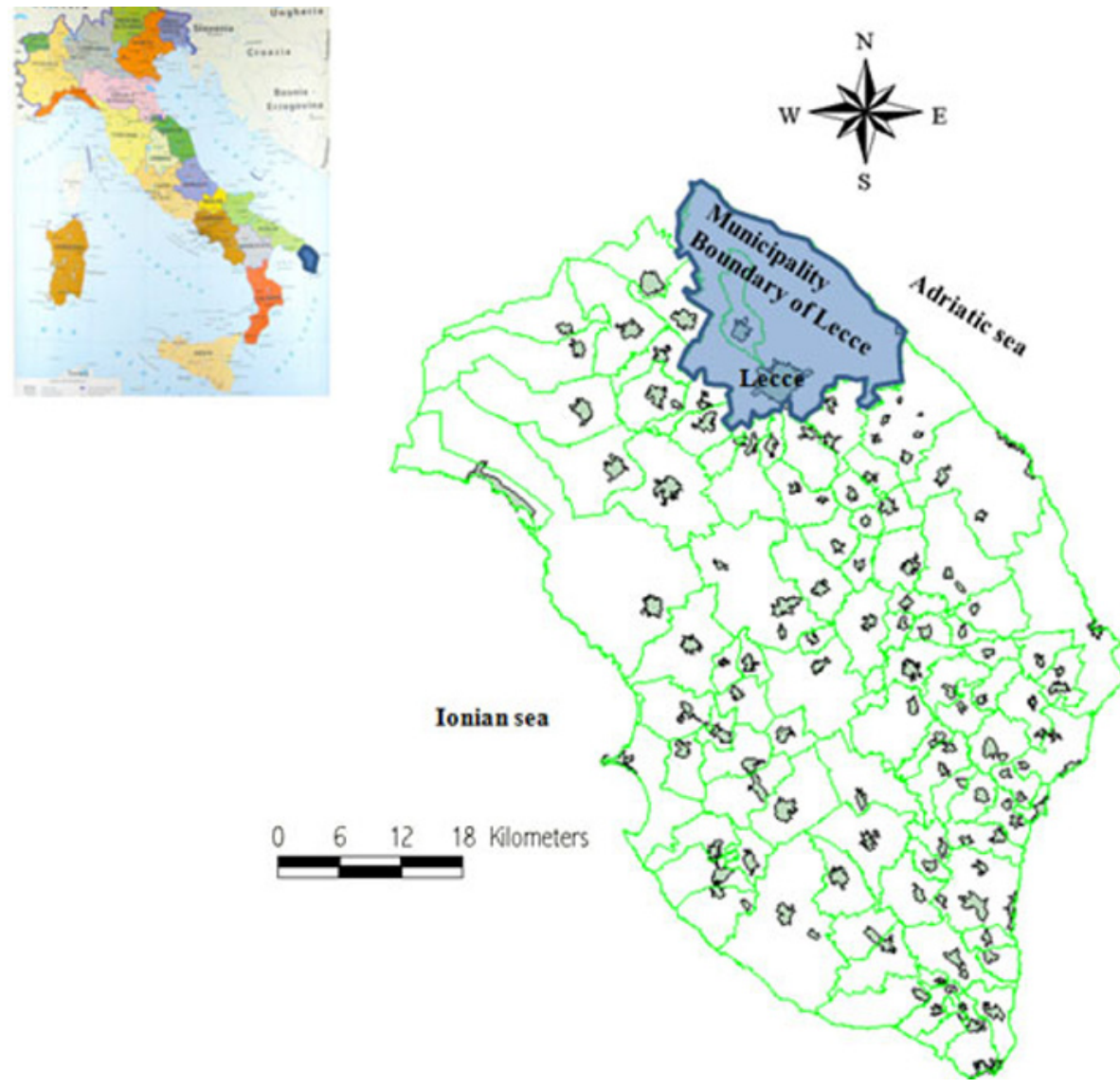

Fig. 1. The study area. Green lines indicate the city boundaries.

nary age (Bossio et al. 1987, D'Alessandro et al. 2004). The mid-southern part of Salento peninsula is marked by a wide endorheic area, bordered both toward the East and the West by degradated fault scarps. Marls, calcareous marls, and calcarenites belonging to several Pleistocene sedimentary cycles extensively crop out in the endorheic area. These deposits cover a stratigraphic sequence compound by calcareous units whose age is comprised between the Upper Cretaceous and the Upper Pliocene. The margins of the endorheic area are shaped on Lowest Pleistocene deposits (Bossio et al. 1987), up to $70 \mathrm{~m}$ thick, made by calcareous, bioclastic sandstones, locally clinostratified; they shade into bluish clayey marls toward centre of the area. The bottom of depressions is covered by thick sandy colluvial deposits. The most part of endorheic area is constituted by a flat surface, gently sloping northeastward, reaching $120 \mathrm{~m}$ of altitude at its SE part. The surface is 

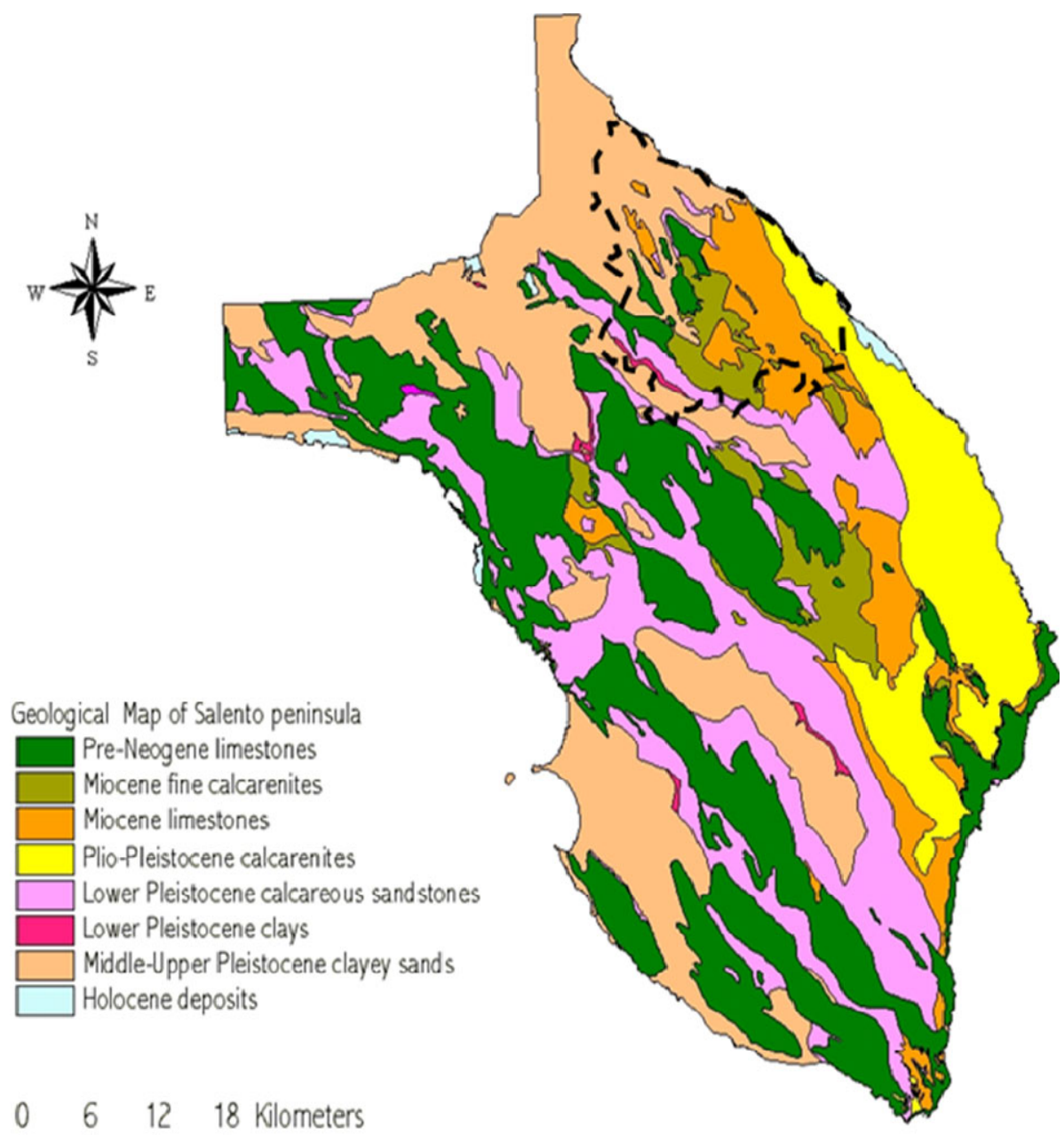

Geological Map of Salento peninsula

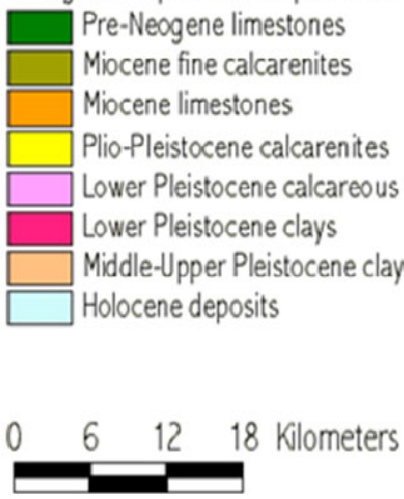

Fig. 2. Geological map of Salento penisula. The dashed dark line marks the boundaries of the study area.

shaped on white quartz sands that can be most likely referred to the Middle Pleistocene. To the north-west, a low relict cliff joins this surface to a wide marine terrace placed between $40-80 \mathrm{~m}$ of altitude whose deposits, made by coarse calcareous sandstones, lie transgressively on the Lower Pleistocene sandy and clayey deposits (Fig. 2) (D'Alessandro et al. 1994). The Salento peninsula is marked by a wide, deep aquifer hosted into the Mesozoic limestones, which remain on sea-water intruded from the nearby coastal areas, according to the Ghyben-Herzberg principle. However, a number of shallow 
water tables occur in the most recent deposits. In particular, in the endorheic area several water tables can be found within the Lower Pleistocene calcareous sandstone and in the Middle Pleistocene sands even if their characteristics are not well known. However, a significant drainage from shallow water tables to the deep acquifer is most likely to occur along subvertical planes of greater hydraulic conductivity (Leucci et al. 2003).

In the study area marked with dashed dark line, on the basis of literature data (Margiotta and Negri 2004) the geological characterization is possible; in particular, the following eight litho-stratigraphical units were discriminated, in order from earliest to latest:

- Altamura limestone (upper Cretaceous),

a Galatone formation (late Oligocene),

$\checkmark$ Lecce formation (late Oligocene - early Miocene),

- Pietra Leccese (Miocene-late Miocene),

- Andrano calcarenites (upper Miocene),

口 Leuca formation (Pliocene),

- Uggiano la Chiesa formation (early-upper Pliocene),

- Gravina calcarenites (Quaternary).

Furthermore, according to the information extrapolated from several wells (Margiotta and Negri 2004), it is possible to highlight that there is a deep aquifer which is under pressure at the bed of the Miocene formation of Lecce stone, which shows a considerable thickness (over $50 \mathrm{~m}$ ) and extending for several meters (also $75 \mathrm{~m}$ ) under the sea level.

Margiotta and Negri (2004) highlighted the presence of four types of shallow aquifers located at different levels. The first three types are hosted in calcareous sediments and calcarenitic, in some cases marly and compact, which according to these characteristics are mainly low permeable. The last type of a shallow aquifer, instead, is hosted in sandy-type sediments, totally permeable, for cracking and porosity. The first aquifer is hosted in sediments of the Oligocene formation of Galatone and Lecce formation. This aquifer is also the most powerful discovery in the area because these surface waters are found from $25 \mathrm{~m}$ below sea level (b.s.l.) and up to $60 \mathrm{~m}$ b.s.l.

The second aquifer is hosted in sediments of Lecce stone and has a slightly smaller power than the last. This pitch was indeed found from a depth of $6 \mathrm{~m}$ above sea level (a.s.1.) up to $6 \mathrm{~m}$ b.s.l., with a total thickness of about $12 \mathrm{~m}$. The third aquifer is hosted in Miocene sediments of the Calcarenite of Andrano, but it has a little thickness: $6 \mathrm{~m}$. The latest aquifer is hosted in Plio-Pleistocene sediments of the Uggiano la Chiesa formation and Leuca formation. This aquifer is small and it has a thickness of about $5 \mathrm{~m}$ and is located entirely above the sea level. 


\section{MATERIALS AND METHODS}

Using the software Groundwater Modeling System (GMS) a 3D geological model, containing lithological information, and a 3D groundwater model, containing water flow velocity, ground water thickness, and water flow direction, are performed. The scope of building a model is to simplify the field problem and organize the field data so that the system can be analyzed more readily (Anderson and Woessner 1992). The conceptualization of the model includes synthesis and framing up of data pertaining to geology, hydrogeology, hydrology, and meteorology.

The lithologic data were collected from 51 lithologs of drinking-water, and irrigation wells (Margiotta and Negri 2004) whose location is shown in Fig. 3. Depth of the lithologs ranges from 70 to $200 \mathrm{~m}$ b.g.l. Based on the acquired lithologs, a lithologic model was developed with Groundwater Modeling System (GMS). The lithologic solid model was created using a block-centric finite-difference grid. The gridding was performed through the eight nearest-neighbor methodology with $3 \mathrm{D}$ interpolation by average minimum distance. The solid model was developed to a depth of about $200 \mathrm{~m}$ b.g.l. The sensitivity of the model was tested by varying the horizontal and vertical spacing of the nodes, and an optimized final model, least sensitive to changes in spatial resolution (i.e., smaller grid sizes) was built. The resolution of the final model was $100 \mathrm{~m} \times 100 \mathrm{~m} \times 2 \mathrm{~m}$. The resulting dis-

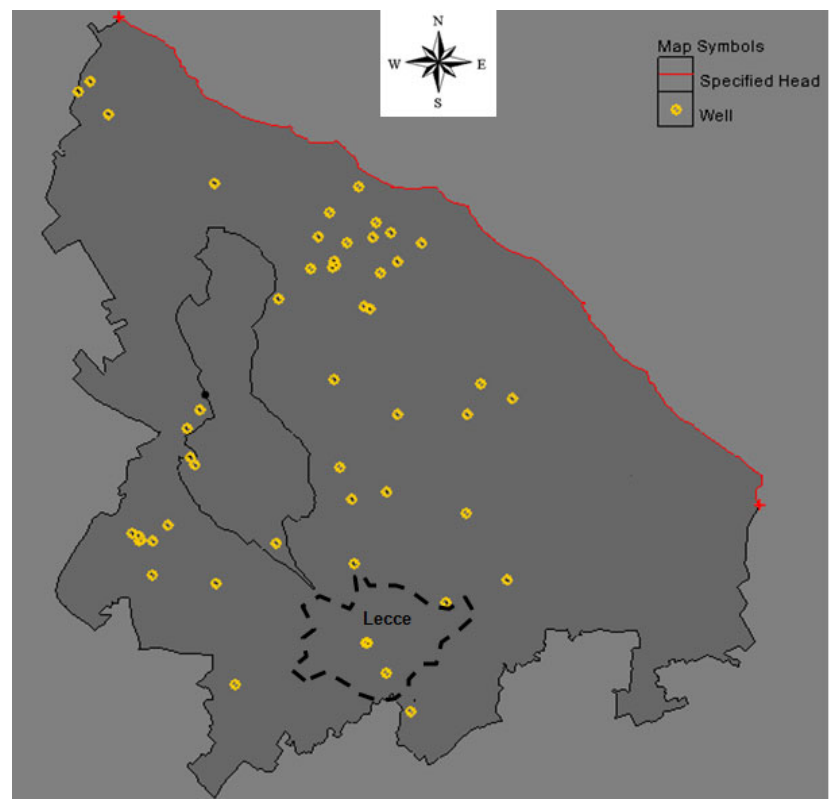

Fig. 3. Location of 51 wells inside the study area. 
cretization consisted of 250 nodes $\times 250$ nodes $\times 100$ nodes, obtaining 6250000 solid model nodes, each with a voxel volume of $20000 \mathrm{~m}^{3}$. It should be noticed that the results of the modeling are not free from uncertainties, which could be reduced by increasing datapoints number, but they illustrate one of the most probable scenarios. The smallest scale of variation that the model is able to depict is equal to the resolution of one voxel.

Given the heterogeneity and complexity associated with the study area (e.g., local-scale variations of aquifer properties, presence of numerous surface water bodies, etc.), some generalizations, simplifications, and assumptions were made to construct the groundwater flow model. The modeled study area is limited in the east by the Adriatic Sea, and it accounts for about $25 \mathrm{~km}$ in length and $25 \mathrm{~km}$ in width. The 3D constant-density groundwater flow was simulated by a block-centric, finite-difference grid model, using MODFLOW code inside GSM software. Furthermore, MODAEM code, which allows the analysis to the analytical elements (polygons, lines, and points), was used. MODAEM was used to extract information related to the depth and thickness of the aquifer inside the area under investigation.

The study area was horizontally discretized in the same way as described in the above paragraph. The maximum thickness of the model was $200 \mathrm{~m}$. The model was vertically discretized in 5 layers. The layers had variable thickness as a result of wells stratigraphy. The 5th layer was defined as the basal no-flow boundary, consistent with the extensive clay layer at about $200 \mathrm{~m}$ below mean see level (m.s.l.). The layers were allowed to have seepage from the top and leakage through the base, making them hydraulically connected. The top-most layer and the second layer were defined as unconfined. The rest of the layers were defined as confined, as the water table was not expected to fall $>60 \mathrm{~m}$ (Leucci et al. 2003).

The conductivity was assigned to layers according to the modeled lithology. Vertical hydraulic conductivity $(\mathrm{kz})$ was ranging from 0.86 to $0.64 \mathrm{~m} / \mathrm{d}$ for the various types of calcarenite present in the study area and ranging from $2 \times 10^{-2}$ to $0.8 \times 10^{-2} \mathrm{~m} / \mathrm{d}$ for the limestone (Sileo 2011). Other parameters were the horizontal anisotropy, the vertical anisotropy, the effective porosity, and the porosity.

What concerns anisotropy ratio, it is related to hydraulic conductivities in different directions. For example, vertical to horizontal hydraulic conductivity anisotropy ratio is given by $k r / k z$, where $k z$ is the vertical hydraulic conductivity and $k r$ is the radial (horizontal) hydraulic conductivity. Anisotropy in a horizontal plane is given by $k x / k y$ where $k x$ and $k y$ are horizontal hydraulic conductivities in the $x$ and $y$ directions, respectively. In the case of the study area, hydraulic conductivity $k x$ ranges from 0.36 to $0.067 \mathrm{~m} / \mathrm{d}$ and for the various types of calcarenite present, and it ranges from 0.025 to $0.032 \mathrm{~m} / \mathrm{d}$ for the limestone (Sileo 2011), while $k y$ ranges from 0.31 to 
$0.054 \mathrm{~m} / \mathrm{d}$ for the various types of calcarenite present, and it ranges from 0.013 to $0.018 \mathrm{~m} / \mathrm{d}$ for the limestone (Sileo 2011). Consequently, the horizontal anisotropy ranges from 1.16 to 1.24 for the various types of calcarenite present in the study area, and it ranges from 1.92 to 1.78 for the limestone. On the other hand, the vertical anisotropy ranges from 0.39 to 0.094 for the various types of calcarenite present and from 0.95 to 0.31 for the limestone.

The total porosity is defined as the fraction of the bulk rock volume $V$ that is not occupied by solid matter. It should be noticed that the porosity does not give any information concerning pore sizes, their distribution, and their degree of connectivity. Thus, rocks characterized by the same porosity could have widely different physical properties. An example of this might be a carbonate rock and a sandstone. Each could have a porosity of 0.2 , but carbonate pores are very often unconnected resulting in its permeability being much lower than that of the sandstone. There is also an "effective" porosity defined as the ratio between the connected pore volume and the total volume (Juhasz 1986, Hill et al. 1979, Clavier et al. 1977). The most common definition of "effective" porosity is (Juhasz 1986, Hill et al. 1979, Clavier et al. 1977):

$$
F e=F t-V_{D},
$$

where $F t$ is the total porosity of clean (clay free) sand, and $V_{D}$ is the volume of dispersed clay in the sand pore space expressed as a fraction of the bulk volume. Sileo (2011) has performed experimental studies on the hydrological characteristics of the calcarenite, some of which are present in the study area, and she has found that the "effective" porosity ranges from 27 to $45 \%$ while the total porosity ranges from 32.4 to $54 \%$.

No detailed previous data on the total recharge were available for the study area and, hence, it was one of the least certain input parameters. The total recharge inflow in the study area can be estimated on the basis of two fundamental sources: (i) precipitation, and (ii) irrigation return flow. In particular, the average annual precipitation was calculated using multiple year data (about 80) for six locations in and near the study, and it is $649.4 \mathrm{~mm}$ (Leucci et al. 2003). The total water from rain available for recharge can be termed as potential recharge (PR) and is defined as follows:

$$
R-E T=P R=A R+S F,
$$

where $R$ is the total precipitation, $E T$ is the evapotranspiration, $S F$ is the surface overflow, and $A R$ is the amount of meteoric water that actually recharges the aquifer. Accurate quantification of $A R$ and $S F$ requires long-term hydraulic head data and surface water stage measurements from multiple lo- 
cations in the study area. Because such data were not available, $A R$ was estimated indirectly by approximation of seasonal $P R$ from meteoric data $(80$ years).

The $P R$ was estimated as a difference of the total precipitation and the $E T$ in a specific area. ET was calculated by the method of Pike (1964) as:

$$
E T[\mathrm{~mm} / \mathrm{month}]=\frac{P}{\left[1+\left(\frac{P}{P E T}\right)^{2}\right]^{1 / 2}},
$$

where $P$ is the average precipitation $[\mathrm{mm} / \mathrm{month}]$, and $P E T$ is the potential evapotranspiration $[\mathrm{mm} / \mathrm{month}]$. Values of $P E T$ were approximated from the method of Malmström (1969):

$$
\operatorname{PET}[\mathrm{mm} / \mathrm{month}]=40.9 \cdot K \cdot \tau,
$$

where $k=0.611 \exp (17.3 \tau / \tau+237.3)$ and $\tau$ is average monthly temperature $\left({ }^{\circ} \mathrm{C}\right)$. The average $P R$ calculated for the study area is $266 \mathrm{~mm} /$ year equal to $41 \%$ of the mean annual rainfall.

These calculated $P R$ data were used to develop zonal recharge values by kriging them in the seasonal flow models.

In the studied area, hydraulic heads in observation wells $(n=51)$ fall in the range between 0.5 and $2.8 \mathrm{~m}$ because of extensive pumping. These withdrawals are replenished yearly, leading to similar groundwater levels at the beginning of each irrigation season. This indicates that the total annual recharge is equal to the difference in groundwater levels between wet and dry seasons.

Furthermore, the ground surface temperature records from ten meteorological stations were studied. The mean temperatures in a range of 15 years on the four seasons were examined. Soil temperature varies temporally and spatially; it is affected mainly by variations in air temperature and solar radiation. These variations influence the temperature at different depths in the subsoil. These variations at several depths in the subsoil can be estimated using a sinusoidal function (Hillel 1982, Marshall and Holmes 1988, Wu and Nofziger 1999). The variation of average soil temperature at different depths is described with the following sinusoidal function (Hillel 1982):

$$
T(z, t)=\left[T_{a}+A_{0} \exp (-z / d)\right] \sin \left[2 \pi\left(t-t_{0}\right) / 365-(z / d)-(\pi / 2)\right],
$$

where $T(z, t)$ is the soil temperature at time $t$ [d] and depth $z[\mathrm{~m}], T_{a}$ is the average soil temperature $\left[{ }^{\circ} \mathrm{C}\right], A_{0}$ is the annual amplitude of the surface soil temperature $\left[{ }^{\circ} \mathrm{C}\right], d$ is the damping depth [m] of annual fluctuation, and $t_{0}$ is the time lag (days) from an arbitrary starting date (taken as 1 January in this 
study) to the occurrence of the minimum temperature in a year. The damping depth is given by $d=\left(2 D_{h} / \omega\right)^{1 / 2}$, where $D_{h}$ is the thermal diffusivity, and $\omega=2 \pi / 365 d^{-1}$.

Amplitude is a parameter characterizing the seasonal variation of soil temperature around an average value. If the variation in temperature within a day is averaged out over many years, the seasonal amplitude is one-half the difference between this seasonal averaged maximum and seasonal averaged minimum temperatures within a season.

Damping depth is a constant characterizing the decrease in amplitude with an increase in distance from the soil surface. It is defined as $\left(2 D_{h} / \omega\right)^{1 / 2}$, where $D_{h}$ is the thermal diffusivity, and $\omega$ is the frequency of a temperature fluctuation. For example, in the annual fluctuation $\omega=2 \pi / 365 d^{-1}$.

Thermal diffusivity (Table 1 ) is the change in temperature produced in a unit volume by the quantity of heat flowing through the volume in unit time under a unit temperature gradient. It can be calculated from thermal conductivity and volumetric heat capacity.

Time lag is the number of days from an arbitrary starting date to the occurrence of the minimum temperature in a year.

Successively, the heat flow in the surveyed area was determined. For this purpose, the aquifer temperature method was used. The heat flow $(q)$ is calculated using the following relation (de Lima Gomes and Hamza 2005):

$$
q=\left[\left(T_{A Q T}-T_{0}\right) /\left(Z_{A Q T}-Z_{0}\right)\right]\left[\left(Z_{A Q T}-Z_{0}\right) / \Sigma_{i} R_{i} h_{i}\right],
$$

Table 1

Mean thermal diffusivity at different depths (D'Arpa et al. 2012)

\begin{tabular}{|c|c|}
\hline $\begin{array}{c}\text { Depth } \\
{[\mathrm{m}]}\end{array}$ & $\begin{array}{c}\text { Mean thermal diffusivity } \\
{\left[10^{-5} \mathrm{~m}^{2} \mathrm{~s}^{-1}\right]}\end{array}$ \\
\hline $0-5$ & 0.123 \\
$6-10$ & 0.303 \\
$11-20$ & 0.829 \\
\hline
\end{tabular}

Table 2

Mean thermal resistivity at different depths (D'Arpa et al. 2012)

\begin{tabular}{|c|c|}
\hline $\begin{array}{c}\text { Depth } \\
{[\mathrm{m}]}\end{array}$ & $\begin{array}{c}\text { Mean thermal resistivity } \\
{\left[{ }^{\circ} \mathrm{C} \mathrm{cm} / \mathrm{W}\right]}\end{array}$ \\
\hline $0-5$ & 50.23 \\
$6-10$ & 56.90 \\
$11-20$ & 69.86 \\
\hline
\end{tabular}


where $T_{A Q T}$ is the temperature at depth $Z_{A Q T}, R$ (Table 2) is the thermal resistivity of the layer with thickness $h$ and $n$ the number of layers, $T_{0}$ is the soil temperature.

In the study area, due to the needs of the municipality of Lecce, one zone was chosen in order to obtain detailed information about stratigraphy, groundwater depth, flow direction, and hydraulic conductivity (Fig. 11). Moreover, in this zone the results of the model flow were validated.

Resistivity imaging system, also called electrical resistivity tomography (ERT) uses 2D and 3D electrical imaging/topography surveys to map areas with complex geology. This kind of survey normally uses a large number of electrodes (may be 25 or more), connected to a multicore cable. The electrode spacing is normally a constant. A laptop computer together with electronic switching is used to automatically select the four relevant electrodes for each measurement (Griffiths and Barker 1993, Loke 2011). Results thus obtained are normally presented as resistivity $2 \mathrm{D}$ and $3 \mathrm{D}$ images with different colour combinations representing different resistivities, as shown later.

Furthermore, ERT method could be considered in order to visualize the change in water content in the subsurface and therefore it allows obtaining a direct measure of hydraulic conductivity. In fact, electrical resistivity is extremely sensitive to subsurface water content. Hydraulic conductivity could be measured using electrical time-lapse resistivity measurements (Binley et al. 2002, Deiana et al. 2007).

The self potential (SP) method is based on measuring the natural direct current potential between any two points on the ground (Telford et al. 1990). The potential differences are partly constant and partly fluctuating and are associated with electrical currents in the ground. Large anomalous potentials are often observed over sulphide and graphite ore bodies, magnetite and several other electrically conductive minerals (Lowrie 2007), and groundwater accumulations (Meisner 1962, Paul 1965). Selfpotential anomalies are also associated with water in subsurface structures and flow of water through the ground (Fig. 15). The streaming self potential of groundwater is usually indicated as a negative anomaly in the profile (Colangelo et al. 2006). Figure 10 represents horizontal groundwater flow (from right to left), which generates SP data as a linearly increasing line in the direction of flow. The slope of the line is a relative measure of the driving hydraulic gradient (Vichabian and Dale Morgan 2002).

\section{RESULTS AND DISCUSSIONS}

\subsection{The geo-lithological model}

The lithologic modeling suggests the presence of a very complex 3D hydrostratigraphic framework in the subsurface of the studied area. A detailed de- 


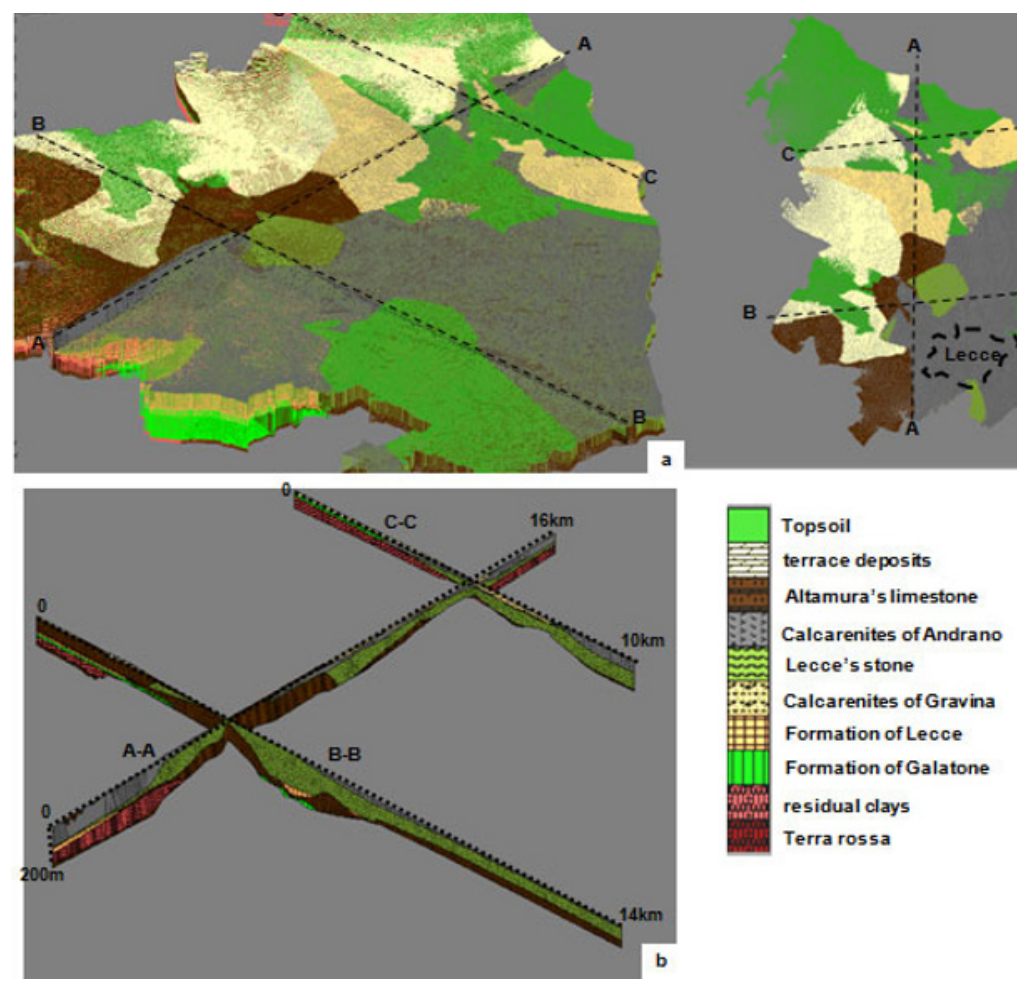

Fig. 4: (a) 3D lithological model, and (b) geological cross-sections.

scription of the study area at the block scale is provided here to illustrate the general spatial trends in aquifer thickness and spatial variability. The 3D lithologic model (Fig. 4a) with the cross-sections in Fig. 4b provide detailed depictions of the geology of the studied area.

\subsection{The groundwater flow model}

The sequence of modeling for the study area is shown in Figs. 5 and 6. Figure 5 shows the groundwater depth level (Fig. 5a) and groundwater thickness (Fig. 5b). As expected, the ground water level ranges between 1 and $58 \mathrm{~m}$. In the south-western part of the study area, a greater depth of groundwater level is seen. In this zone, groundwater is at about $4.5 \mathrm{~m}$ a.s.1. It represents the second aquifer hosted in sediments of Lecce stone.

The velocity flow model (Fig. 6) suggests that it was topographically controlled. The groundwater flow velocity ranging from $5 \times 10^{-8}$ to $14.5 \times 10^{-8} \mathrm{~m} / \mathrm{s}$ and its direction is essentially from the southern boundary of the study area to the north-west. 


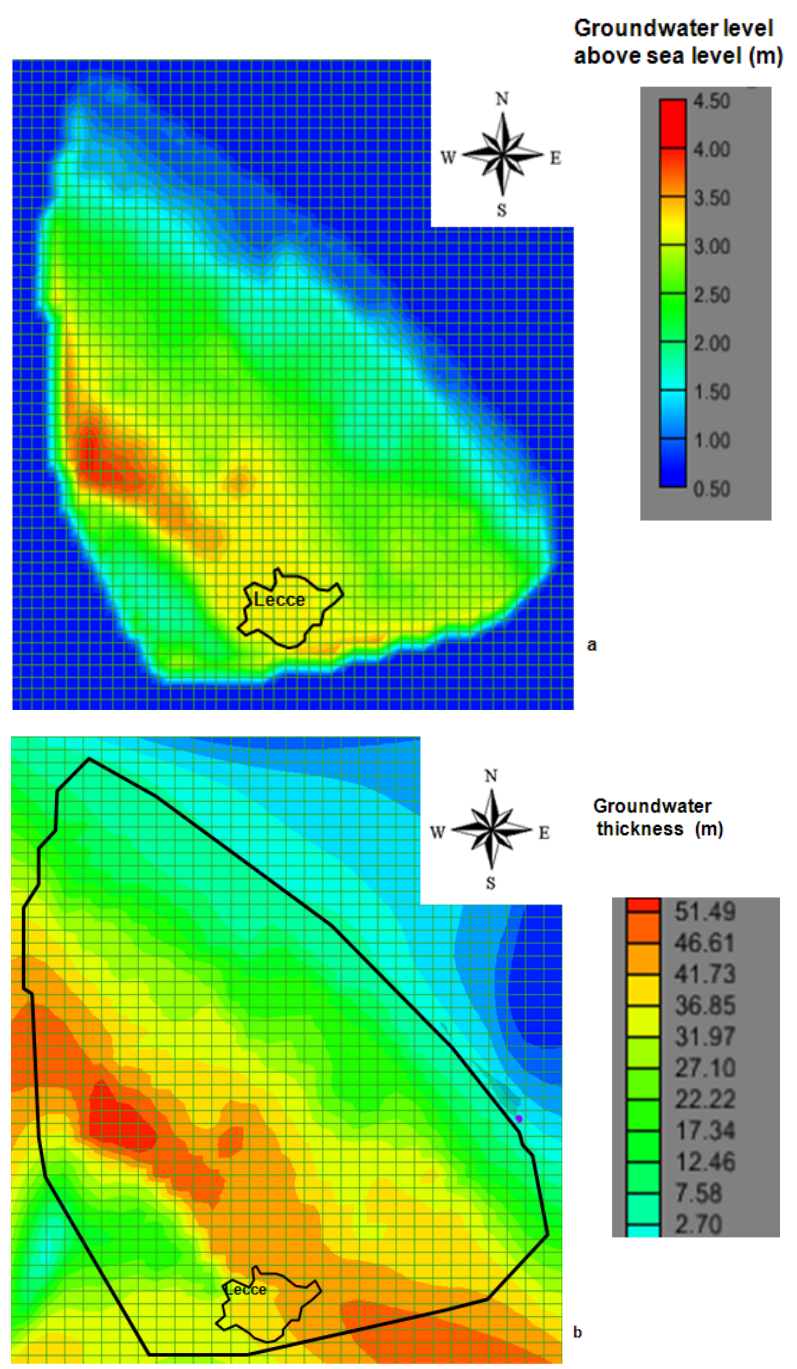

Groundwater level

below ground surface $(\mathrm{m})$

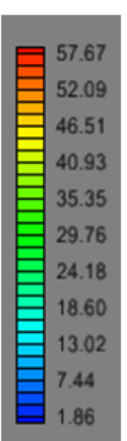

Fig. 5. The second aquifer hosted in sediments of Lecce stone: (a) groundwater depth level, and (b) ground water thickness.

\subsection{The ground temperature model}

Soil temperature data at different depths for the study area are shown in Fig. 7.

In autumn, the temperature ranged from 19 to $22^{\circ} \mathrm{C}$ at the soil surface, while at the $10 \mathrm{~m}$ depth it ranged from 20.5 to $24.6^{\circ} \mathrm{C}$. At the $20 \mathrm{~m}$ depth it ranged from 18 to $21^{\circ} \mathrm{C}$. 


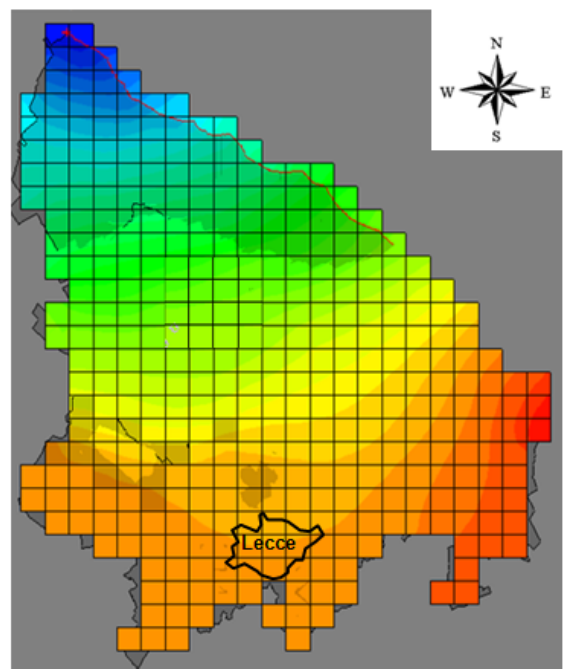

\section{Groundwater flow} velocity $\left(\times 10^{-8} \mathrm{~m} / \mathrm{s}\right)$

\begin{tabular}{|l|}
14.28 \\
13.64 \\
13.00 \\
12.36 \\
11.73 \\
11.09 \\
10.45 \\
9.81 \\
9.17 \\
8.54 \\
7.90 \\
7.26 \\
6.62 \\
5.99 \\
5.35 \\
\hline
\end{tabular}

Fig. 6. Groundwater velocity flow model.
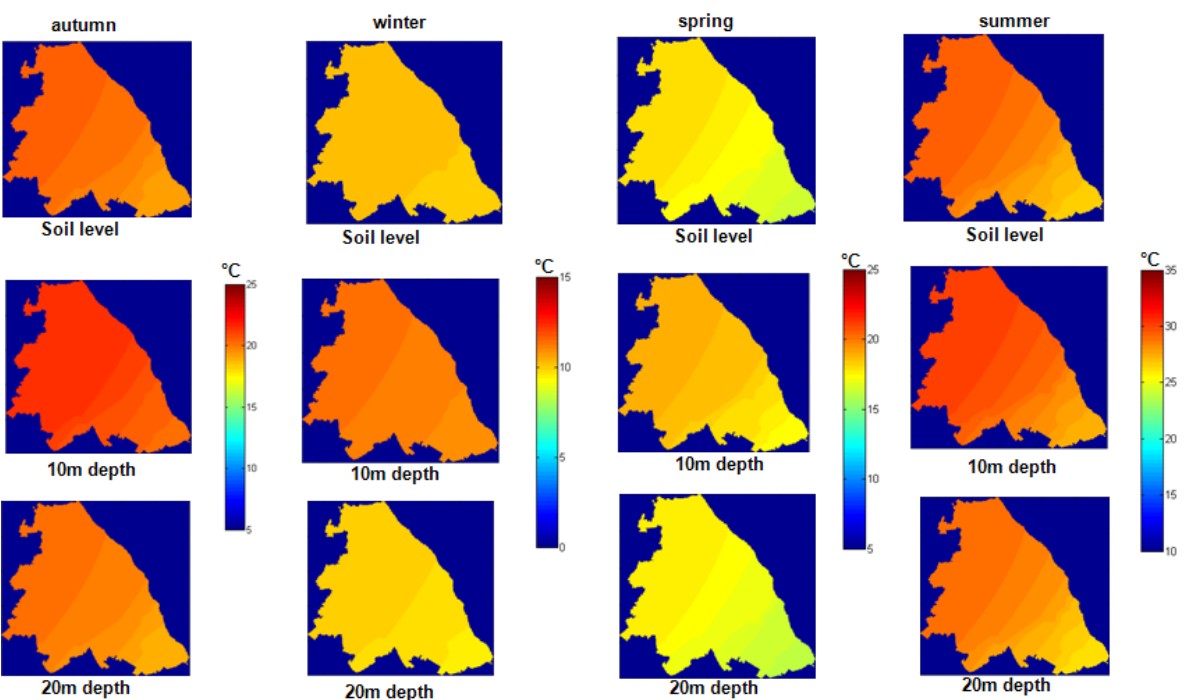

Fig. 7. Seasonal soil temperature map at different depths for the study area.

In winter, the temperature ranged from 10 to $12^{\circ} \mathrm{C}$ at the soil surface, while at the $10 \mathrm{~m}$ depth it ranged from 11 to $13^{\circ} \mathrm{C}$. At the $20 \mathrm{~m}$ depth it ranged from 10 to $11^{\circ} \mathrm{C}$.

In spring, the temperature ranged from 16 to $20^{\circ} \mathrm{C}$ at the soil surface, while at the $10 \mathrm{~m}$ depth it ranged from 17 to $21^{\circ} \mathrm{C}$. At the $20 \mathrm{~m}$ depth it ranged from 16 to $19.4^{\circ} \mathrm{C}$. 


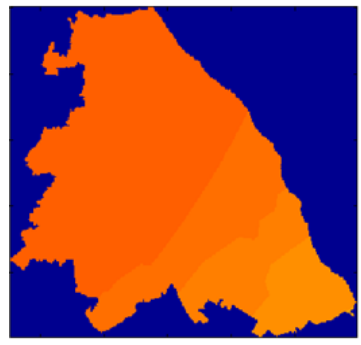

Soil level

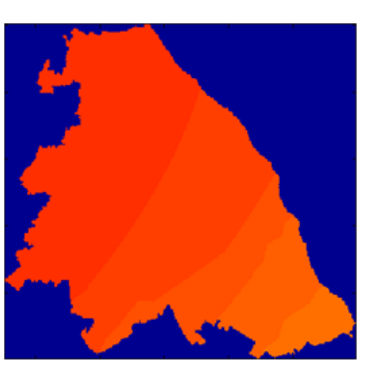

$10 \mathrm{~m}$ depth

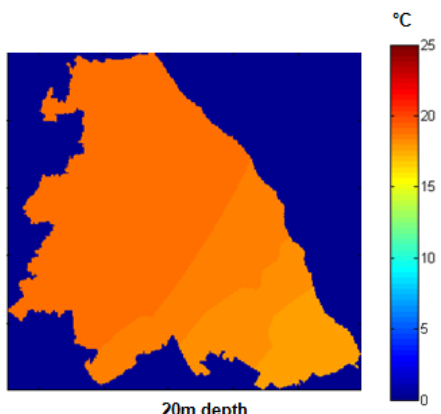

$20 \mathrm{~m}$ depth

Fig. 8. Annual soil temperature map at different depths for the study area.

In summer, the temperature ranged from 26 to $33^{\circ} \mathrm{C}$ at the soil surface, while at the $10 \mathrm{~m}$ depth it ranged from 27 to $34^{\circ} \mathrm{C}$. At the $20 \mathrm{~m}$ depth it ranged from 26 to $30^{\circ} \mathrm{C}$.

The annual soil temperature data at different depths for the study area are shows in Fig. 8. Here, the temperature ranged from 16 to $22^{\circ} \mathrm{C}$ at the soil surface, while at the $10 \mathrm{~m}$ depth it ranged from 18 to $24^{\circ} \mathrm{C}$. At the $20 \mathrm{~m}$ depth it ranged from 16 to $22^{\circ} \mathrm{C}$.

\subsection{The heat flow model}

The first step in the heat flow determination was the evaluation of groundwater temperature in the study area. For this purpose, a geostatistical analy-
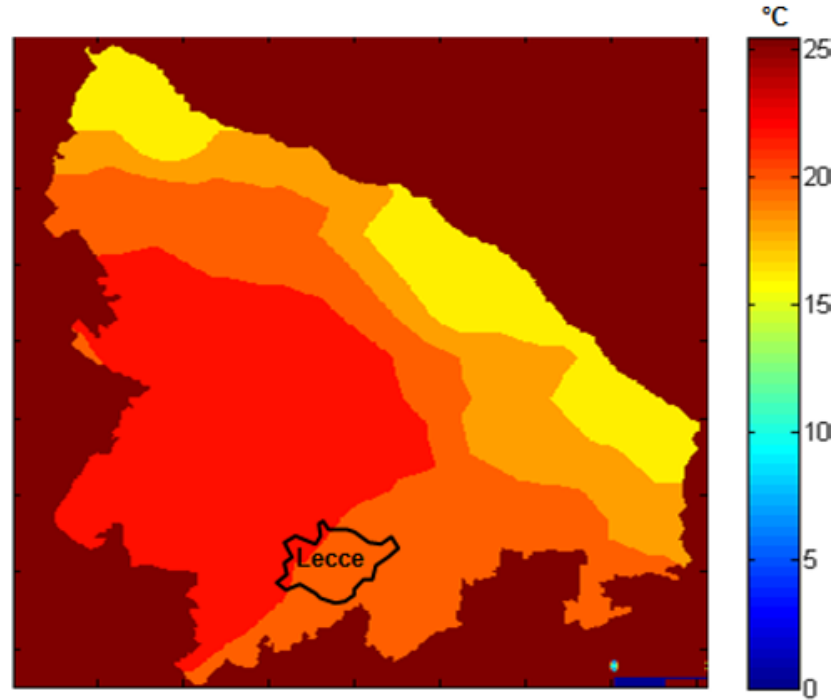

Fig. 9. Annual groundwater temperature map for the study area. 

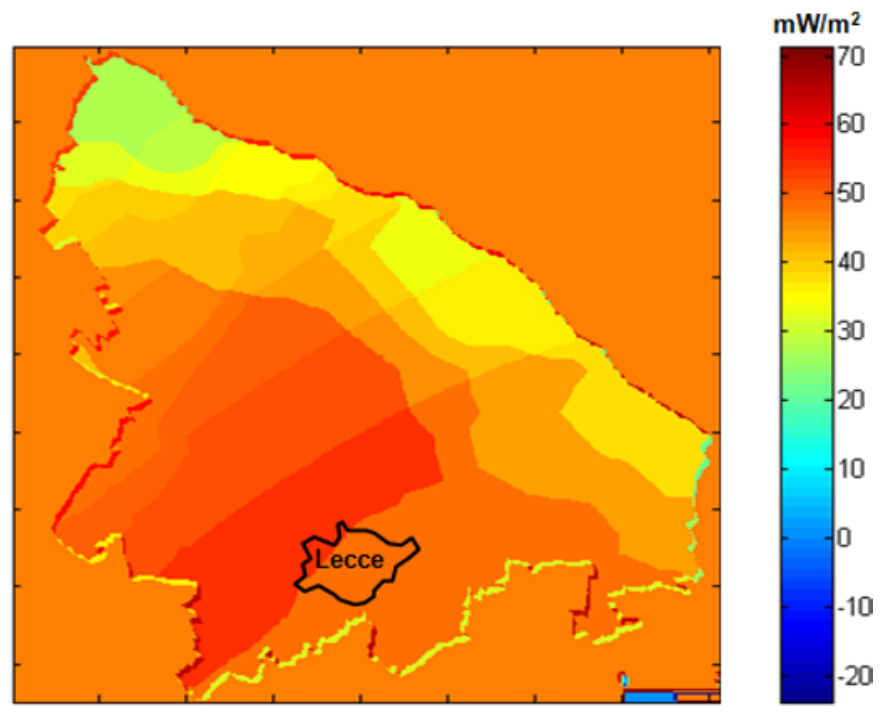

Fig. 10. Heat flow map for the study area.

sis was performed on the annual temperature data from the 51 wells used for the lithological model in Section 4.1. The groundwater temperature map is shows in Fig. 9. Here at the temperatures ranged from 16 to $22^{\circ} \mathrm{C}$.

Based on this map and Table 2, Eq. 6 allows to make the heat flow map in the study area (Fig. 10). The heat flow map reveals that the heat flow is in the range of 25 to $65 \mathrm{~mW} / \mathrm{m}^{2}$. Heat flow values lower than $30 \mathrm{~mW} / \mathrm{m}^{2}$ were encountered on the sea line. Heat flow values higher than $50 \mathrm{~mW} / \mathrm{m}^{2}$ were found in the south western parts of the study area. It appears that the heat flow regime of the eastern part of the study area is distinctly different from that of the western part.

\subsection{D ERT time lapse measurements}

In order to obtain detailed information about stratigraphy and groundwater depth in the selected zone (Fig. 11), the first geophysical measurement was the ERT time lapse in order to obtain information about the hydraulic conductivity.

The ERT data were collected in a straight-line array of 24 electrodes with $5 \mathrm{~m}$ spacing, W-E oriented. The Wenner array was chosen because it provides a good signal-to-noise ratio. Additionally, it is also highly sensitive to vertical changes in the subsurface resistivity. This makes the Wenner array a useful tool in studying the movement of the wetting front in time. The investigation depth was about $20 \mathrm{~m}$, easily achievable with the chosen elec- 


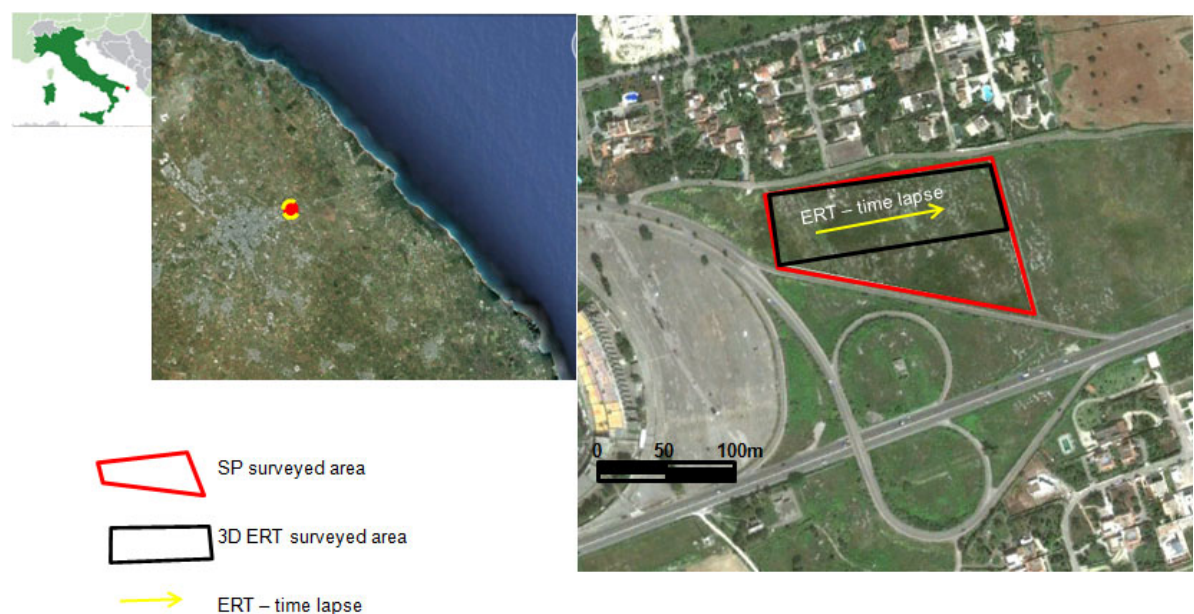

Fig. 11. The time-lapse ERT profile, 3D ERT area, and SP location in the selected zone.

trode configuration. The IRIS-SYSCAL Pro Switch 48 instrument was used to acquire electrical resistivity measurements.

To obtain 2D resistivity models, the field data were inverted using Res2Dinv software (Griffiths and Barker 1993, Loke and Barker 1996). In the processing of resistivity data, an inversion routine based on the smoothness-constrained least-squares method was implemented (deGroot-Hedlin and Constable 1990). The 2D model used by the inversion program divides the subsurface into a number of rectangular blocks, whose arrangement is linked to the distribution of points in pseudosections. The distribution and size of the blocks is generated automatically by the program, using the distribution of the data points as a rough guide. The depth of the bottom row of blocks is set to be approximately equal to the equivalent depth of investigation (Edwards 1977) of the data points. The optimization method basically tries to reduce the difference between the calculated and measured apparent resistivity values, by adjusting the resistivity of the model blocks. A forward modeling subroutine is used to calculate the apparent resistivity values, and a non-linear least-squares optimization technique is used for the inversion routine (Loke and Barker 1996). A measure of this difference is given by the root-mean squared (RMS) error.

The objective of these measurements was to obtain the field hydraulic conductivity. The water was inserted using a large ring infiltrometer installed directly at the $x$-axis of between 30 and 40 and between 80 and $90 \mathrm{~m}$ along the ERT profile above the ground surface in both tests. First measurements were performed before the water was inserted (Fig. 12a). The water pumps were used in order to insert water in the ring infiltrometer. A stratigraphy 

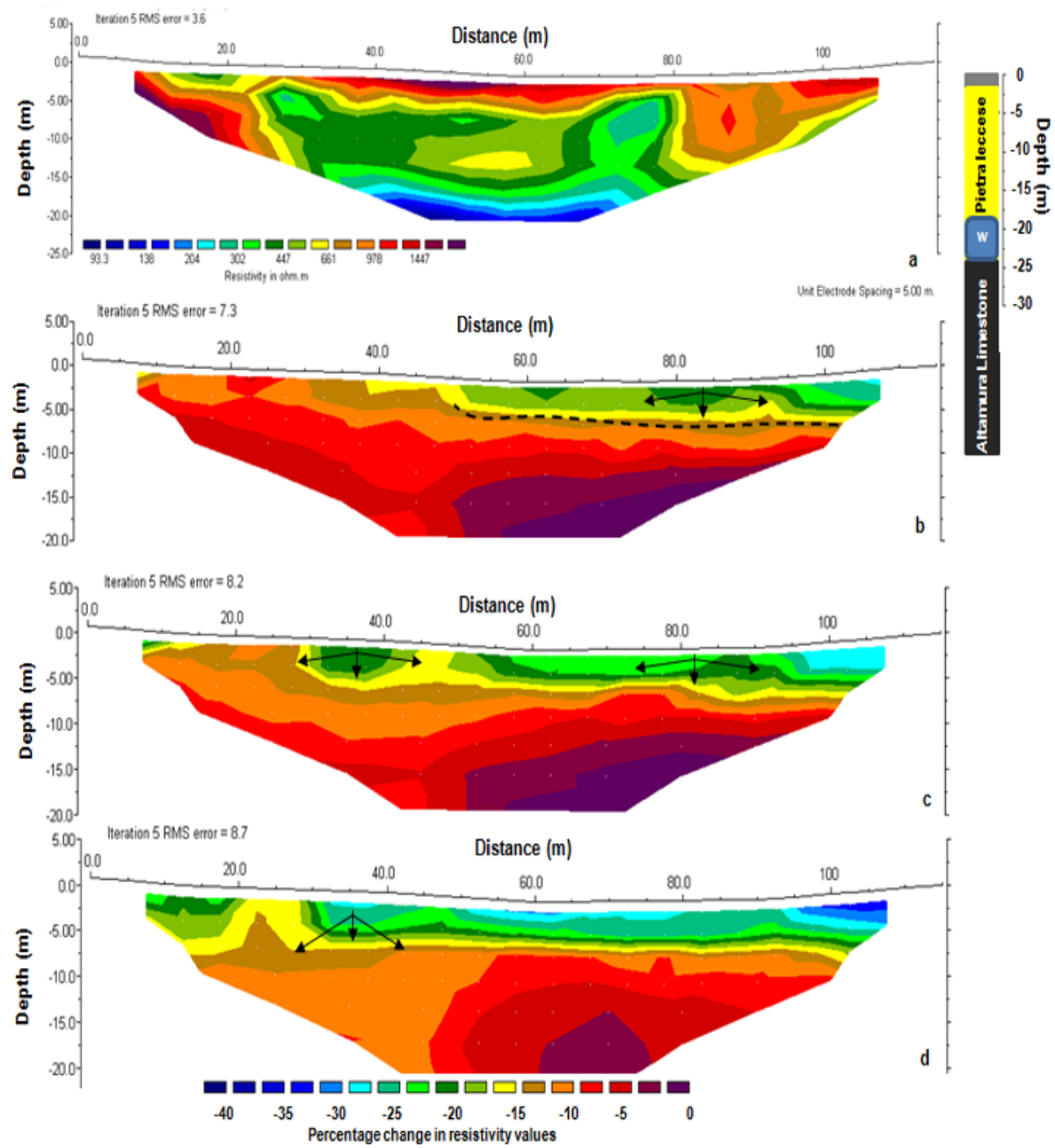

Fig. 12. Time lapse model: (a) resistivity distribution in dry condition, (b) percentage resistivity model during approximately 3 days of water infiltration, (c) percentage resistivity model during approximately 6 days of water infiltration, and (d) percentage resistivity model during approximately 22 days of water infiltration.

available and related to a well located near the investigated area allows to have a control on the results of the ERT profile. It is possible to notice a first layer composed by topsoil. The second layer is the Pietra Leccese, which was associated with the resistivity values ranging from 300 to $1400 \mathrm{ohm} \mathrm{m}$ (about $16 \mathrm{~m}$ thickness). The wide range of variability of the values of resistivity could be due to both the degree of fracturing and the variation of the water content within the Pietra Leccese. At about $18 \mathrm{~m}$ in depth, it is 
possible to evidence the water table with resistivity values ranging from 90 to $110 \mathrm{ohm} \mathrm{m}$.

During approximately 3 days of the water infiltration (Fig. 12b), the specific resistivity changed by about $17 \%$ while the infiltrating water has reached a depth of $4 \mathrm{~m}$ vertically and traveled $20 \mathrm{~m}$ horizontally. Probably, this is due to the high fracture degree.

In the sixth day of the water infiltration (Fig. 12c), the specific resistivity changes were of about $5-10 \%$ at depths between about 5 and $10 \mathrm{~m}$.

In the twenty-second day of the water infiltration (Fig. 12d), the specific resistivity changes were of about $8 \%$ at depths between about 5 and $20 \mathrm{~m}$.

During the experiment, the resistivity decreased, on the average, by $10 \%$ in the first $20 \mathrm{~m}$ depth. Therefore, water has traveled vertically an average of $0.9 \mathrm{~m} / \mathrm{d}$. Horizontally, the water has traveled an average of $7 \mathrm{~m}$ in twentytwo days $(0.35 \mathrm{~m} / \mathrm{d})$. These values are in agreement with the values found experimentally on several calcarenite samples by Sileo (2011).

\subsection{D ERT measurements}

A 48-channel Syscal-Pro Resistivity-meter was used for the survey. Resistivity field data were collected in a rectangular area of 235 by $60 \mathrm{~m}$, along $5 \mathrm{~m}$ spaced parallel profiles oriented approximately W-E (Fig. 11). For each profile, 48 electrodes were used.

The multi-electrodes field procedure using the Wenner electrodes arrangement was applied to fulfill the resistivity measurements. The electrode separation was $5 \mathrm{~m}$.

The measured data were processed by means of 3D inverse modelling software (ERTLab by Geostudy Astier). Its numerical core is based on tetrahedral Finite Elements (Zienkiewicz and Taylor 1989, Cifuentes and Kalbag 1992).

The 3D image of resistivity is shown in Fig. 13. The 3D visualization proposed in Fig. 13a shows the resistivity distribution of the upper $40 \mathrm{~m}$ in which it is possible to note:

(i) a zone of low resistivity (about $450-500 \mathrm{ohm} \mathrm{m}$ ), from the surface to about $3 \mathrm{~m}$ in depth;

(ii) a zone in which resistivity values range between 700 and $850 \mathrm{ohm} \mathrm{m}$, from about $3 \mathrm{~m}$ to about $10 \mathrm{~m}$ of depth;

(iii) a zone with resistivity values ranging between 300 and $450 \mathrm{ohm} \mathrm{m}$, from about 10 to about $20 \mathrm{~m}$ of depth;

(iv) a water table zone located between about 20 and $40 \mathrm{~m}$ depth.

The 3D images of resistivity can easily be visualized by 3D contouring of iso-resistivity volumes (Fig. 13b). In this representation, the transparency function is defined by two threshold values of the resistivity, $\rho_{1}$ and $\rho_{2}$ 


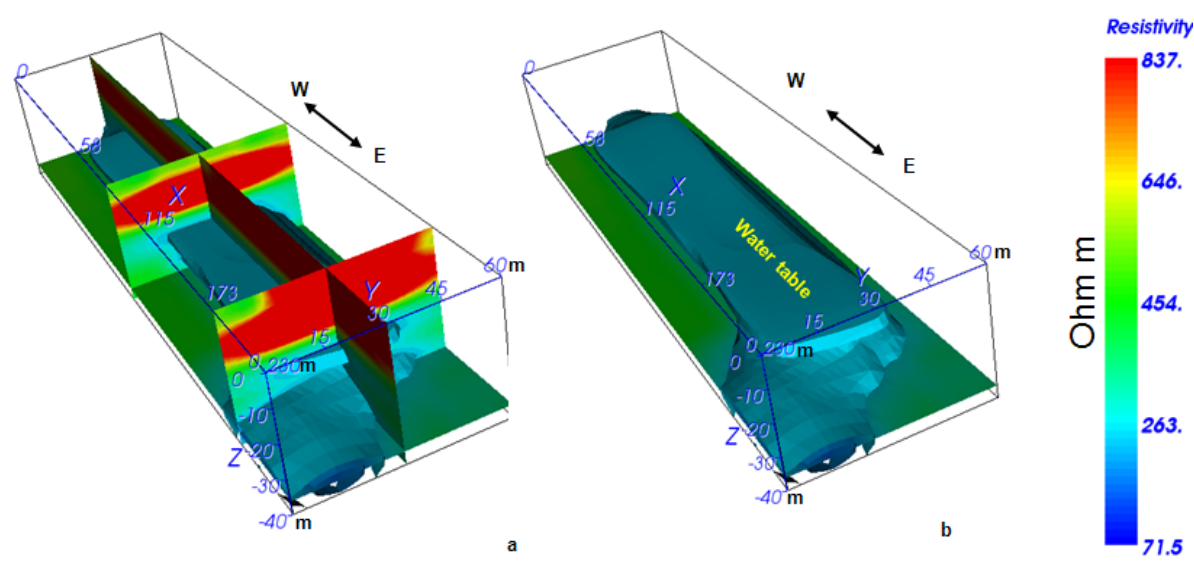

Fig. 13. The 3D ERT results: (a) resistivity distribution of the upper $40 \mathrm{~m}$, and (b) iso-resistivity volume using a threshold values ranging from 70 to $110 \mathrm{ohm}$.

$\left(\rho_{1}<\rho_{2}\right)$. In the intervals $\rho<\rho_{1}$ and $\rho>\rho_{2}$, data are rendered as transparent; therefore, only the data in the interval $\rho_{1}<\rho<\rho_{2}$ are visualized. In Fig. 13b, the resistivity data set is displayed with iso-resistivity volumes using a threshold value ranging from 70 to $110 \mathrm{ohm} \mathrm{m}$. The continuous highresistivity area, interpreted as water table, is more visible.

\subsection{D SP measurements}

The SP measurements covered the 3D ERT surveyed area (Fig. 11). The self-potential signals were measured at the ground surface in a set of 432 measurement points located along nine parallel lines.

Each electrode (stainless and nonpolarizing) was placed inside a $10 \mathrm{~cm}$ deep hole, filled with a moistened bentonite and gypsum mixture to ensure good contact between the electrode and the ground, and stones were placed above the electrodes. Measurements of the self-potential signals were carried out with a Keithley 2701 multichannel voltmeter, and we used nonpolarizing $\mathrm{Pb} / \mathrm{PbCl} 2$ (Petiau) electrodes (Perrier et al. 1997). The voltmeter was connected to a laptop computer where the data were recorded. All the electrodes were scanned during a period of $30 \mathrm{~s}$.

The SP data were filtered with a low-pass filter in the frequency domain in order to avoid edge effects of space domain filters, so that high frequencies were eliminated and low frequencies were preserved (Aubanel and Oldham 1985). These data are used to build self-potential map shown in Fig. 14.

Self-potential anomalies vary in value according to their source (Reynolds 1998). If the value of self-potential is positive or negative of onehundred millivolts, the cause is the movement of ground water. Is important 


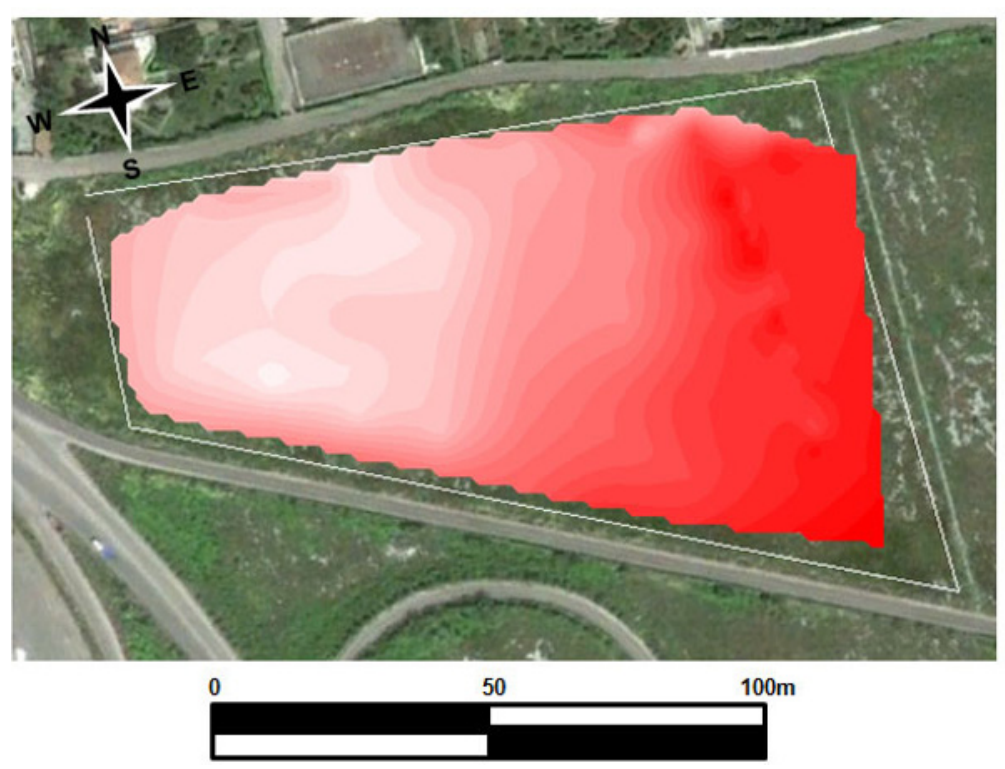

$\mathrm{SP}(\mathrm{mV})$

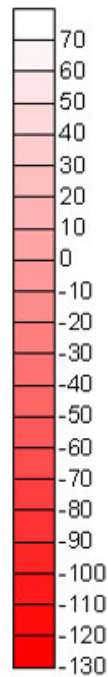

Fig. 14. The self-potential distribution map in the selected zone.

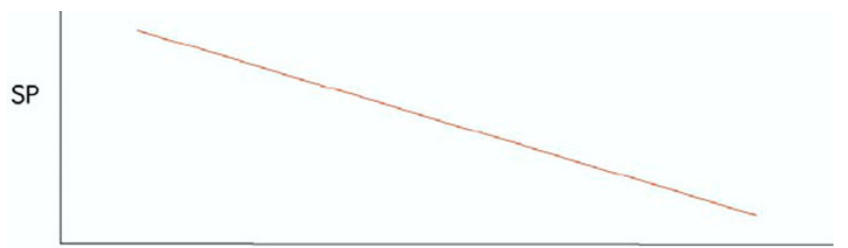

Distance

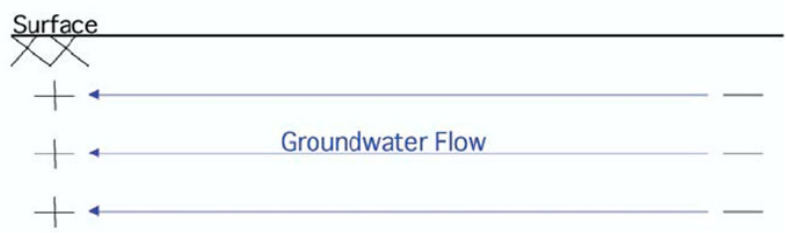

Fig. 15. Schematic response of self-potential distribution in the subsoil with associated water flow.

to note that the water flow direction is from negative to positive values of self-potential (Fig. 15). The result of this research shows that the selfpotential values vary between -130 and $70 \mathrm{mV}$ at a distance of approximately $230 \mathrm{~m}$. This result can be interpreted as being due to a movement of groundwater due to the water table at about $20 \mathrm{~m}$ depth. 
Figure 14 helps us to understand the complexity in local water flow direction that mainly confirms the predominant north-west direction and confirms the results of ground water flow model.

\section{CONCLUSIONS}

The proposed study allows the identification of areas suitable for the utilization of low enthalpy geothermal energy. For the studied area, data from stratigraphical information relative to 51 wells were collected. These data were integrated with geophysical data. This allowed the identification of the local geology, and particularly the depth of the groundwater table and the principal directions of the groundwater flow. The identification of the local geology (lithological classification) to determine subsoil physical characteristics (such as thermal resistivity, thermal diffusivity) related to the studied site was made. Furthermore, the ground surface temperature records from ten meteorological stations allowed us to model the variations of temperature at different depths in the subsoil.

The major findings of this research can be summarized as follows:

口 The mean value of geothermal gradient was $0.2^{\circ} \mathrm{C} / \mathrm{m}$;

a The ground-water temperature varies from 16 to $22{ }^{\circ} \mathrm{C}$. It seem to influence the subsoil temperature variations at $20 \mathrm{~m}$ depth;

口 The estimated heat flow ranges from 25 to $65 \mathrm{~mW} / \mathrm{m}^{2}$, with a mean value of $45 \mathrm{~mW} / \mathrm{m}^{2}$. It is higher in the northwestern part of the periphery of Lecce;

- The ground-water flow direction was north-west according to the hydroizohypses distribution of 51 analyzed wells;

- The velocity flow model suggests that it was topographically controlled and its velocity was ranging from $5 \times 10^{-8}$ to $14.5 \times 10^{-8} \mathrm{~m} / \mathrm{s}$;

a The geophysical survey makes it possible to give detailed information relating to the investigated zone that confirms the results of the model;

- This information allows establishing, within the same areas, the most suitable points for the installation of a geothermal low enthalpy plants.

Anderson, M.P., and W.W. Woessner (1992), Applied Groundwater Modeling: Simulation of Flow and Advective Transport, Academic Press Inc., San Diego, $381 \mathrm{pp}$. 
Andersson, O. (2007), Aquifer thermal energy storage (ATES). In: H.Ö Paksoy (ed.), Thermal Energy Storage for Sustainable Consumption, Springer, Berlin Heidelberg, 155-176, DOI: 10.1007/978-1-4020-5290-3_8.

Aubanel, E.E., and K.B. Oldham (1985), Fourier smoothing without the fast Fourier transform, Byte 10, 2, 207-218.

Benderitter, Y., and G. Cormy (1990), Possible approach to geothermal research and relative cost estimante. In: M.H. Dickson, and M. Fanelli (eds.), Small Geothermal Resources, UNITAR/UNDP Centre for Small Energy Resources, Rome, Italy, 61-71.

Bergkamp, G., and K. Cross (2006), Groundwater and Ecosystem Services: towards their sustainable use. In: Proc. Int. Symp. on Groundwater Sustainability (ISGWAS), Alicante, Spain, 177-193, http://aguas.igme.es/igme/ISGWAS/ Ponencias\%20ISGWAS/13-Bergkamp.pdf.

Binley, A., G. Cassiani, R. Middleton, and P. Winship (2002), Vadose zone flow model parameterisation using cross-borehole radar and resistivity imaging, J. Hydrol. 267, 3-4, 147-159, DOI: 10.1016/S0022-1694(02)00146-4.

Bosellini, A., F.R. Bosellini, M.L. Colalongo, M. Parente, A. Russo, and A. Vescogni (1999), Stratigraphic architecture of the Salento coast from Capo d'Otranto to S. Maria di Leuca (Apulia, southern Italy), Riv. Ital. Paleontol. S. 105, 3, 397-416.

Bossio, A., F. Guelfi, R. Mazzei, B. Monteforti, and G. Salvatorini (1987), Studies on the Neogene and Quaternary of Salento peninsula. III - Stratigraphy of the well of Poggiardo, Quad. Ric. Centro Studi Geotecn. d'Ing. Lecce 11, 55-88 (in Italian).

Bossio, A., R. Mazzei, B. Monteforti, and G. Salvatorini (1992), Preliminary news about the Miocene of S. Maria al Bagno - S. Caterina, at Nardo (Lecce), Paleopelagos 2, 99-107 (in Italian).

Bossio, A., F. Guelfi, R. Mazzei, B. Monteforti, and G. Salvatorini (1994), The Miocene succession of the Calcareniti of Andrano (Puglia, southern Italy), Boll. Soc. Paleont. It. 33, 2, 249-255 (in Italian).

Bossio, A., D. Esu, L.M. Foresi, O. Girotti, A. Iannone, E. Luperto, S. Margiotta, R. Mazzei, B. Monteforti, G. Ricchetti, and G. Salvatorini (1998), Formation of Galatone, the new name for a lithostratigraphic unit of Salento (Puglia, southern Italy), Atti Soc. Tosc. Sc. Nat. Mem. A 105, 151-156 (in Italian).

Bossio, A., L. Foresi, S. Margiotta, R. Mazzei, B. Monteforti, and G. Salvatorini (1999), Geological map of the north east of the province of Lecce, scale of 1: 25000; sector 7, 8, 10 scale 1: 10000, Università degli Studi di Siena (in Italian).

Cifuentes, A.O., and A. Kalbag (1992), A performance study of tetrahedral and hexahedral elements in 3-D finite element structural analysis, Finite Elem. Anal. Des. 12, 3-4, 313-318, DOI: 10.1016/0168-874X(92)90040-J. 
Clavier, C., G. Coates, and J. Dumanoir (1997), Theoretical and experimental bases for the dual-water model for interpretation of shaly sands. In: Proc. 52nd Annual Meeting, Society of Petroleum Engineering, Denver, USA, Rep. SPE-6859-PA, preprint $16 \mathrm{pp}$.

Colangelo, G., V. Lapenna, A. Perrone, S. Piscitelli, and L. Telesca (2006), 2D selfpotential tomographies for studying groundwater flows in the Varco d'Izzo landslide (Basilicata, southern Italy), Eng. Geol. 88, 3, 274-286, DOI: 10.1016/j.enggeo.2006.09.014.

Costanza, R., R. d'Arge, R. de Groot, S. Farber, M. Grasso, B. Hannon, K. Limburg, S. Naeem, R.V. O’Neill, J. Paruelo, R.G. Raskin, P. Sutton, and M. van den Belt (1997), The value of the world's ecosystem services and natural capital, Nature 387, 253-260, DOI: 10.1038/387253a0.

D’Alessandro, A., G. Mastronuzzi, G. Palmentola, and P. Sansò (1994), Pleistocene deposits of Salento leccese (Southern Italy): problematic relationships, Boll. Soc. Paleont. It. 33, 2, 257-263.

D’Alessandro, A., F. Massari, E. Davaud, and G. Ghibaudo (2004), PliocenePleistocene sequences bounded by subaerial unconformities within foramol ramp calcarenites and mixed deposits (Salento, SE Italy), Sediment. Geol. 166, 1-2, 89-144, DOI: 10.1016/j.sedgeo.2003.11.017.

D’Arpa, S., N. Zaccarelli, D.E. Bruno, G. Leucci, V.F. Uricchio, and G. Zurlini (2012), A geographically weighted regression model for geothermal potential assessment in mediterranean cultural landscape. In: Proc. EGU General Assembly, 22-27 April 2012, Vienna, Austria, 12432.

de Groot-Hedlin, C., and S. Constable (1990), Occam's inversion to generate smooth, two-dimensional models form magnetotelluric data, Geophysics 55, 12, 1613-1624, DOI: 10.1190/1.1442813.

de Jesus, A.C. (1997), Environmental sustainability of geothermal development, Energ. Source. 19, 1, 35-47, DOI: 10.1080/00908319708908830.

de Lima Gomes, A.J., and V.M. Hamza (2005), Geothermal gradient and heat flow in the state of Rio de Janeiro, Rev. Brasil. Geofis. 23, 4, 325-347, DOI: 10.1590/S0102-261X2005000400001.

Deiana, R., G. Cassiani, A. Kemna, A. Villa, V. Bruno, and A. Bagliani (2007), An experiment of non-invasive characterization of the vadose zone via water injection and cross-hole time-lapse geophysical monitoring, Near Surf. Geophys. 5, 3,183-194, DOI: 10.3997/1873-0604.2006030.

Dickson, M.H., and M. Fanelli (2004), What is Geothermal Energy? Instituo di Geoscienze e Georisorce, Pisa, Italy.

Edwards, L.S. (1977), A modified pseudosection for resistivity and IP, Geophysics 42, 5, 1020-1036, DOI: 10.1190/1.1440762.

Falkenmark, M., and J. Rockström (2004), Balancing Water for Humans and Nature: The New Approach in Ecohydrology, Earthscan, London, 247 pp. 
FAO (2003), Groundwater Management - The Search for Practical Approaches, Water Reports 25, Food and Agriculture Organization of the United Nations, Rome, Italy.

Griffiths, D.H., and R.D. Barker (1993), Two-dimensional resistivity imaging and modelling in areas of complex geology, J. Appl. Geophys. 29, 3-4, 211-226, DOI: 10.1016/0926-9851(93)90005-J.

Haenel, R., L. Rybach, and L. Stegena (1988), Fundamentals of geothermics. In: R. Haenel, L. Rybach, and L. Stegena (eds.), Handbook of Terrestrial Heat-Flow Density Determination, Kluwer Academic Publ., Dordrecht, 9-57, DOI: 10.1007/978-94-009-2847-3_2.

Herman, J.S., D.C. Culver, and J. Salzman (2001), Groundwater ecosystems and the service of water purification, Stanford Environ. Law J. 20, 479-495.

Hill, H.J., O.J. Shirley, and G.E. Klein (1979), Bound water in shaley sands - its relation to Qv and other formation properties, The Log Analyst 20, 3, 3-19.

Hillel, D. (1982), Introduction to Soil Physics, Academic Press, NewYork.

Hochstein, M.P. (1990), Classification and assessment of geothermal resources. In: M.H. Dickson and M. Fanelli (eds.), Small Geothermal Resources A Guide to Development and Utilization, UNITAR/UNDP Centre for Small Energy Resources, Rome, Italy, 31-59.

Juhasz, I. (1986), Assessment of the distribution of shale, porosity and hydrocarbon saturation in shaly sands. In: Trans. Soc. Professional Well Log Analysts 10th European Formation Evaluation Symposium, Aberdeen, Scotland, Ch. 15 , paper AA.

Lee, K.C. (2001), Classification of geothermal resources by exergy, Geothermics 30, 4, 431-442, DOI: 10.1016/S0375-6505(00)00056-0.

Leucci, G., S. Margiotta, S. Negri, L. Nuzzo, P. Sansò, G. Selleri, and A. Varola (2003), Integrated geophysical, geological and geomorphological investigations for study the impact of agricultural activities on a complex karstic area. In: Proc. SAGEEP 2003, Environmental and Engineering Geophysical Society, 6-10 April 2003, Saint Antonio, USA, 1162-1179.

Loke, M.H. (2011), Electrical imaging surveys for environmental and engineering studies. A practical guide to 2-D and 3-D surveys: RES2DINV Manual, IRIS Instruments, http://www.iris-instruments.com.

Loke, M.H., and R.D. Barker (1996), Rapid least-squares inversion of apparent resistivity pseudosections by a quasi-Newton method, Geophys. Prospect. 44, 1, 131-152, DOI: 10.1111/j.1365-2478.1996.tb00142.x.

Lowrie, W. (2007), Fundamentals of Geophysics, Cambridge University Press, Cambridge.

Lund, J.W. (2007), Characteristics, development, and utilization of geothermal resources, Geo-Heat Cent. Bull. 28, 2, 1-9.

Malanson, G.P. (1993), Riparian Landscapes, Cambridge Studies in Ecology, Cambridge University Press, Cambridge. 
Malmström, V.H. (1969), A new approach to the classification of climate, J. Geogr. 68, 6, 351-357, DOI: 10.1080/00221346908981131.

Margiotta, S. (1999), The contact between the formation of Galatone and formation of Lecce: stratigraphic and sedimentological evidence, Atti Soc. Tosc. Sc. Nat. Mem. A 106, 73-77 (in Italian).

Margiotta, S., and S. Negri (2004), In search of water lost. New knowledge subsoil in Salento Lecce, Univ. degli Studi di Lecce (in Italian).

Margiotta, S., and G. Ricchetti (2002), Stratigraphy of oligomiocenici deposits of Salento (Puglia), Boll. Soc. Geol. It. 121, 2, 243-252 (in Italian).

Marshall, T.J., and J.W. Holmes (1988), Soil Physics, 2nd ed., Cambridge University Press, New York, 374 pp.

MEA (2005), Ecosystems and Human Well-Being: Wetlands and Water. Synthesis, Millennium Ecosystem Assessment, World Resources Institute, Washington, D.C.

Meiser, P. (1962), A method of quantitative interpretation of selfpotential measurements, Geophys. Prospect. 10, 2, 203-218, DOI: 10.1111/j.1365-2478.1962. tb02009.x.

Meyers, R.A. (ed.) (1992), Encyclopedia of Physical Science and Technology, Academic Press, San Diego.

Morris, B.L., A.R.L. Lawrence, P.J.C. Chilton, B. Adams, R.C. Calow, and B.A. Klinck (2003), Groundwater and its susceptibility to degradation: A global assessment of the problem and options for management, Early Warning and Assessment Report series, RS 03-3, United Nations Environment Programme, Nairobi, Kenya.

Muffler, P., and R. Cataldi (1978), Methods for regional assessment of geothermal resources, Geothermics 7, 2-4, 53-89, DOI: 10.1016/0375-6505(78)90002-0.

Paul, M.K. (1965), Direct interpretation of self-potential anomalies caused by inclined sheets of infinite horizontal extensions, Geophysics 30, 3, 418-423, DOI: 10.1190/1.1439596.

Perrier, F.E., G. Petiau, G. Clerc, V. Bogorodsky, E. Erkul, L. Jouniaux, D. Lesmes, J. Macnae, J.M. Meunier, D. Morgan, D. Nascimento, G. Oettinger, G. Schwarz, H. Toh, M.J. Valiant, K. Vozoff, and O. Yazici-Cakin (1997), A one-year systematic study of electrodes for long period measurements of the electric field in geophysical environments, J. Geomagn. Geoelectr. 49, 11-12, 1677-1696, DOI: 10.5636/jgg.49.1677.

Pike, J.G. (1964), The estimation of annual run-off from meteorological data in a tropical climate, J. Hydrol. 2, 2, 116-123, DOI: 10.1016/0022-1694(64) 90022-8.

Reynolds, J.M. (1998), An Introduction to Applied and Environmental Geophysics, John Wiley \& Sons Ltd., Chichester.

Shaw, E.M. (1994), Hydrology in Practice, 3rd ed., Chapman and Hall, London. 
Sileo, M. (2011), Individuazione e caratterizzazione geologica, chimico-mineralogica e petrofisica di calcareniti tenere della Puglia e della Basilicata in relazione alle problematiche di provenienza e conservazione dei Beni Culturali, Ph.D. Thesis, University of Basilicata, Potenza, Italy (in Italian).

Telford, W.M., L.P. Geldart, and R.E. Sheriff (1990), Applied Geophysics, Cambridge University Press, Cambridge.

Vichabian, Y., and F.D. Morgan (2002), Self potentials in cave detection, The Leading Edge 21, 9, 866-871, DOI: 10.1190/1.1508953.

Ward, R.C., and M. Robinson (1990), Principles of Hydrology, 3rd ed., McGrawHill Book Co., London.

Williamson, L., and N. McCormick (2008), Energy, ecosystems and livelihoods: understanding linkages in the face of climate change impacts, International Union for Conservation of Nature (IUCN), https://www.iucn.org/about/ work/Initiatives/energy_welcome/index.cfm?uNewsID=1646.

Wu, J., and D.L. Nofziger (1999), Incorporating temperature effects on pesticide degradation into a management model, J. Environ. Qual. 28, 1, 92-100, DOI: $10.2134 /$ jeq1999.00472425002800010010x.

Zienkiewicz, O.C., and R.L. Taylor (1989), The Finite Element Method: Basic Formulation and Linear Problems, McGraw-Hill Book Co., London, 648 pp.

Received 23 August 2013

Received in revised form 9 February 2014

Accepted 18 March 2014 